\title{
STATE POLICY FOR ENSURING BUDGETARY SECURITY OF UKRAINE IN TERMS OF FINANCIAL GLOBALIZATION
}

\author{
Zakharii Varnalii \\ Department of Finance, Faculty of Economics, Taras Shevchenko National University of \\ Kyiv, Kyiv, Ukraine
}

\section{Svitlana Onyshchenko}

Department of Finance, Banking and Taxation, Institute of Finance, Economy and Management, National University "Yuri Kondratyuk Poltava Polytechnic", Poltava, Ukraine

\section{Olena Filonych}

Department of Finance, Banking and Taxation, Institute of Finance, Economy and Management, National University "Yuri Kondratyuk Poltava Polytechnic", Poltava, Ukraine

\section{Oleksandra Maslii}

Department of Finance, Banking and Taxation, Institute of Finance, Economy and Management, National University "Yuri Kondratyuk Poltava Polytechnic", Poltava, Ukraine

\begin{abstract}
The basis for the stable functioning of the national economy in general and the financial system in particular is a budget system. Therefore, solving the problem of ensuring the state policy of budget security is one of the primary challenges, due to increasing financial globalization. The purpose of the article is development the theoretical and methodological substantiation of the state policy of ensuring budgetary security of the state and directions of the national economy steadiness increase. Conceptual basis of the budget security are developed and its place in the system of state economic security is defined. It has been determined that state budget is a systemically important state budget security element, and a form of budget security aspect is reflected in the system of assessments that characterizes its level in dynamics and relatively optimal value of indicators and integral index. The object of budget security is the level of state budget execution, efficiency of the budget resources usage, budget process, and budget system. The subject of budget security is activity of state authorities, financial institutions, and budget policy instruments aimed at the implementation of an adequate level of budget security. The strategic priorities and criteria of the state policy on budgetary safety strengthening that provide formation of the favorable macroeconomic environment, development of the real
\end{abstract}


economy, stability of the state finances and solvency of the state are offered. The applied recommendations create a sound basis for building an entire system for ensuring state policy of budget security of Ukraine.

Key words: budget security, national economic, state finance, budget system, state policy, financial globalization, provisioning mechanism, threat, public debt management, strategic priorities

Cite this Article: Zakharii Varnalii, Svitlana Onyshchenko, Olena Filonych and Oleksandra Maslii, State Policy for Ensuring Budgetary Security of Ukraine in Terms of Financial Globalization, International Journal of Management, 11(12), 2020, pp 2283-2292.

http://iaeme.com/Home/issue/IJM?Volume=11\&Issue=12

\section{INTRODUCTION}

Research on the budget security at this stage due to the fact that Ukraine has long state budget deficit, which requires the use of additional resources in the form of external and internal borrowing money costs.

Of particular relevance research budget state security gets in the financial globalization, which is characterized by high intensity and dynamism. This significantly affects the status and problems of ensuring not only budget security, but also all other components of national security of Ukraine.

Today, financial globalization as an integrated objective process is the result of in-depth financial ties, price liberalization and investment flows, creating global multinational financial groups. It produces a dual impact on the global financial system, and fundamentally changing policy priorities. At the same time, financial globalization is forcing national financial systems to function under new management models, standards, controls, mechanisms, rules and regulations.

At the present stage of science development budget security as an economic category is insufficiently studied and is considered mainly under financial or economic security.

Ukraine is facing extremely complex and responsible tasks related to the scale of global problems that are on the agenda and constitute significant threats to Ukraine's state policy and budget security by hampering the effective development of the national economy.

The basis of the state financial stability under globalization is improvement the budget process and directions on the effective budget system formation from the standpoint of safe development, while the proper place should be given to the issues of strengthening the state budgetary security.

The mentioned above actualizes an in-depth study of the theoretical and methodological foundations of ensuring state policy of budget security and the directions of its provision.

\section{LITERATURE REVIEW}

Conceptual approaches to the definition of the essence and content of the budget security concept have been investigated by such experts as O. Baranovsky, D. Brook, Z. Varnalii, I. Ringel, A. Tishler, O. Vlasyuk, J. Cramer, G. Darnopich, V. Varenyk, D. Weisstanner, M. Yermoshenko, T. Lutsyk-Dubova.

O. Kolisnyk considers budget security in ensuring the strategy of socio-economic development of the state [20]. V. Martyniuk separates the budget component and explores the threats and influence factors [8]. Studies of theoretical analysis on budgetary security are provided in works by V. Muntian, G. Pasternak-Taranushenko and S. Pyrozhkov [13] and 
others. Still modern economic science lacks unambiguity in defining the notion of "budget security", theoretical substantiation of the essence and specifics as well as directions of its provision; so many questions are open and controversial. Dynamics and polystructure of processes forming a budget security ensuring system as well as their inadequate theoretical and methodological foundation require systematic scientific approach to the stated problem. The current study of the principles of budget and other constituents of the state economic security ensuring is relevant.

\section{MATERIALS AND METHODS OF STUDY}

The main principles of the state budget security are thematically revealed within the theory of state finances, budget and economic security. At the basis of budget security theoretical generalization, the initial categories and related concepts such as "budget", "budget process", "budget system", "security", "state policy", "budget security" are defined. Structural and functional analysis has been used to systematize the evolution of the state budget security scientific concepts. The preference is given to system approach as far as it is aimed at defining the essence of the state budget security subject and the process as an independent system having numerous elements and relations concerning research subject formation and development. It is the budget system, which possesses the leading role in the state financial system.

In fact, there is no component of national security that would not directly depend on the level of the state budgetary security and state policy. In terms of European integration and financial globalization, each country seeks to preserve its financial independence, and therefore the state budget security is the dominant source of financial security. At the same time, the level of budget security is interdependent and interrelated with other components of the state national security.

At the current stage of security science development, budget security as an economic category, is poorly investigated and is mainly considered under financial or economic security.

Despite the urgency of the problem, today there is no single universally accepted definition for the essence of budget security; the semantics and morphology for this concept vary depending on the tasks, place, as well as the presence of internal and external threats at this stage of society development.

When considering the budget security of the national economy from the standpoint of the system approach, it should be presented in the state economic security system, taking into account the provisions of the current legislation and guidance materials, that is, and the method of regular relation of the system elements.

The system-forming element of budget security of the state is the state budget and state policy, which is a multi-aspect concept. As an instrument of state policy, budget plays a key role in ensuring social and economic development of the state and realization of its national interests, namely: the volume and structure of the revenue and expenditure parts of the budget influence the functioning of all economy sectors.

In the scientific literature there are three main conceptual approaches to the definition of the essence of the state budgetary security, but some scholars propose to consider this category comprehensively by combining existing approaches.

The system approach, as a general scientific methodological direction of research, involves revealing the phenomenon essence, object and process as independent systems and have an integral set of elements and sets of relations between them. 
The definition of the state budget security within the framework of the first conceptual approach is set out in the Methodological Recommendations on the calculation the level of Ukraine's economic security. Also, the vast majority of scholars hold the first position, according to which the essence of budget security is considered as a condition of solvency and financial sustainability of public finances, which enables state authorities to perform their functions as effectively as possible.

Budget security of the state is an integral part of Ukraine's financial security subsystem, which is to preserve the financial system balance, ordering of intersystem links and elements determined by the purpose of the system functioning as a whole and the development of each of the subsystems.

An element of the system is a system component, which is conventionally considered as indivisible depending on the specific research tasks. Elements of the Ukrainian economic security system are industrial, macroeconomic, foreign economic, energy, investment and innovation, social, demographic and food components (see Figure 1).

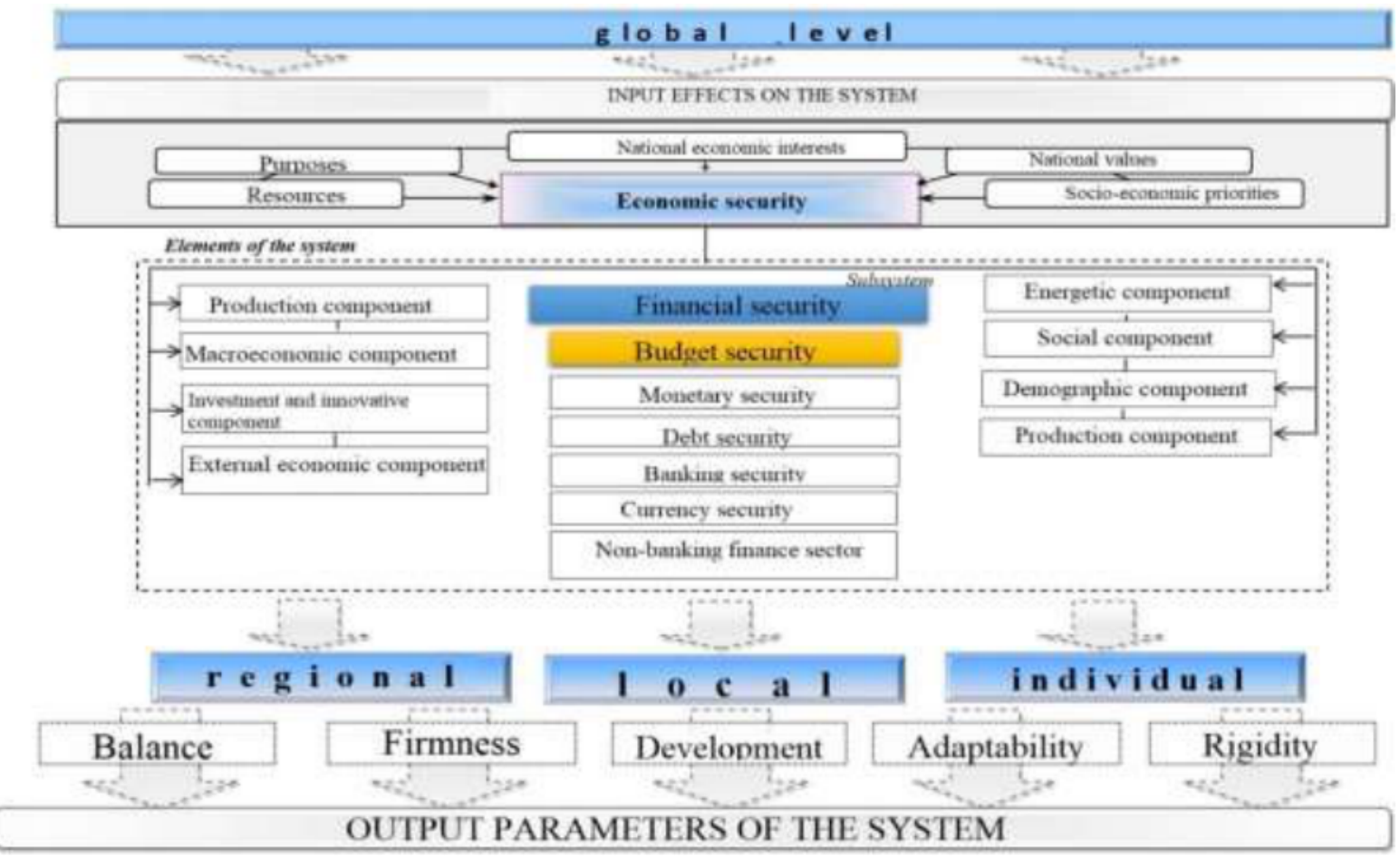

Figure 1 The place of budget security in the state economic security system

A subsystem is a part of a system where, unlike a system element, it is possible to distinguish other components. Such a subsystem of Ukraine's economic security is financial security, which, in its turn, has six components: banking security, security of the non-bank financial market, debt, budget, currency and monetary security.

The elements and subsystems as a whole are components of the state economic security system and state policy. Such division of the system into separate elements and subsystems according to the system approach is ambiguous; it was carried out in order to study the integral level of the state economic security.

The ratio between the components of the system is based on interdependence and inter conditionality is determined by the notion of «relation». The main characteristics of the state budget security are public finances stability, the state budget balance, the effective use of budget funds, the balance of external and internal debt, which creates the necessary financial 
conditions for a stable social and economic development in the country shows the decomposition of the Ukrainian budget security structure as a complex economic category.

The study of state policy and budgetary security also requires a dualistic theoretical approach as far as the level of ensuring the functional capacity of the budget (security of the budget itself) at all levels of the budget system and at all stages of the budget process, and as a basis for ensuring the ability of the state and local self-government bodies to perform their functions (the budget as the basis of the budget security of the state). Figure 2 shows the decomposition of budget security.

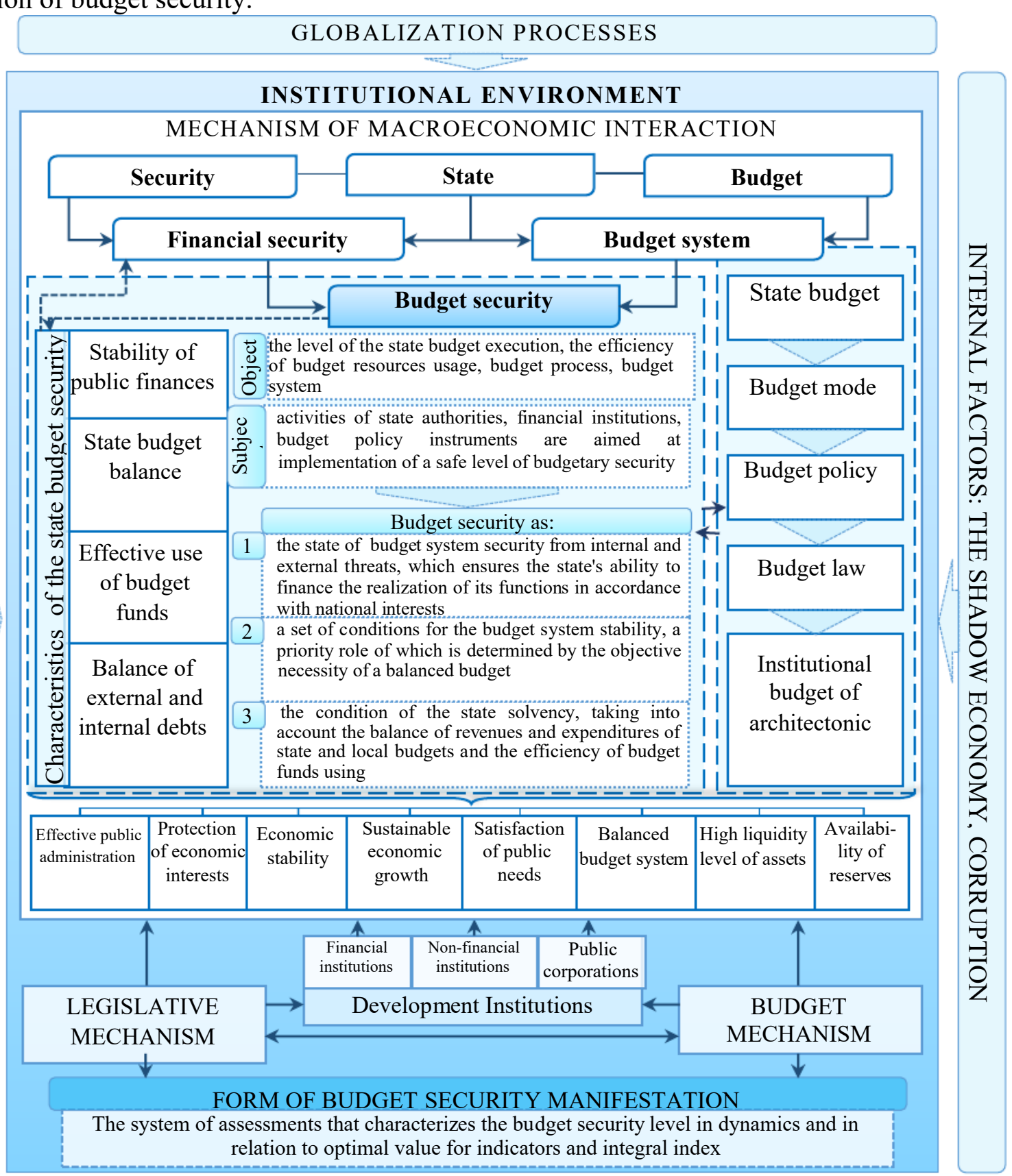

Figure 2 Decomposition of the Ukrainian budget security structure

\section{Source: developed by the authors}

Under modern conditions, one of the most important economic problems in Ukraine is the growing financial, in particular budget, security threats and threats to state policy. This is due to the negative dynamics of the most destabilizing processes in the financial and economic 
sphere, including the disruption in the system of public and business entities finances, which is increasing during the recent years; therefore we consider it appropriate to use a protective approach to the interpretation of the concept of "the state budget security". Protective approach is the most widespread in the budget security study, where protection against a variety of risks, threats and dangers is vital.

In the specific subject field, the study of budget security is considered as a condition for the budget system functioning, which forces state institutions to detect, prevent, minimize or overcome the effects of internal and external threats.

It is expedient to consider the state budget security in two aspects of its manifestation: on the one hand, as an characteristic feature of the budget, which is its ability to function (security of the budget itself) at all levels of the budget system and at all stages of the budget process; and, on the other hand, as the basis for state funding through the budget by state authorities and local self-government as the basis for the achievement of national economic interests.

In view of the above mentioned, and based on the own ground works, we propose to consider the concepts within the functional and protective approach, namely, budget security as the level of the budget system ability, which provides for solvency and the state financial stability, effective use of budget funds, taking into account strategic priorities for budget relations development and the potential to confront and prevent internal and external threats.

The form of the budget security is embodied in the system of assessments that characterize its level in dynamics and the relatively optimal value of indicators and integral index.

The object of budget security is the level of the state budget implementation, the efficiency of using budget resources, budget process, and budget system. The subject of budget security is the activity of state authorities, financial institutions, and budgetary policy instruments aimed at implementing a safe level of budgetary security.

\section{RESULTS OF STUDY}

Trends in the global community determine the dominant role of progressive public policy and state policy in budget security ensuring. Budget policy in Ukraine should be based on the implementation of the developed countries best experience in strengthening the financial framework of the state budget, increasing the responsibility of the budget process participants, increasing transparency at all stages of the budget process, developing medium-term budget planning and the program-target method, which can become an effective direction to increase the effectiveness of the participants of the budget process in Ukraine and contribute to raising the level of budget security of the state (developed by authors and generalized in Figure 3).

In the strategic planning, budget security is guaranteed only by a competitive economy and state policy, which can be built exclusively through the revival and accelerated development of promising sectors of the national economy under sound budget policies. Instead, now there is a tendency to only take measures to stabilize the political and social and economic situation in Ukraine. 
Main aim is to ensure safe budget system functioning in terms of financial globalization by preventing threats of external and internal origin

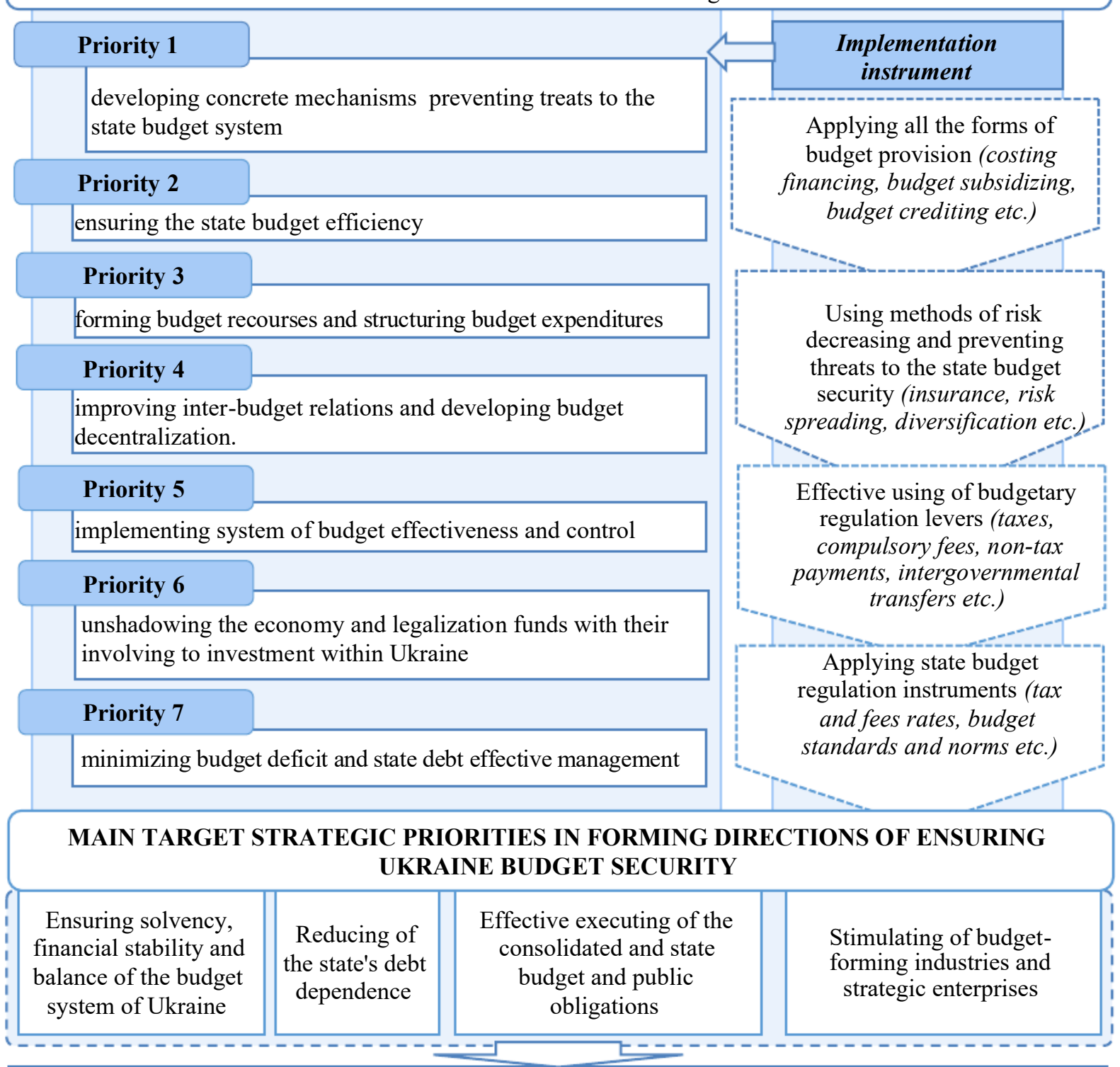

\section{ENSURING STATE NATIONAL SECURITY AND IMPLENTING NATIONAL ECONOMIC INTERESTS}

Figure 3 Strategic priorities for ensuring Ukraine budget security

Source: developed by authors

The main task of the state financial policy in the context of strengthening budget security is to create such an economic, social, political and legal environment, and institutional support that would stimulate the balancing of the budget and tax process.

This process has to be followed by realization of appropriate priorities for budget security strengthening, the most actual among which are the following:

- developing concrete mechanisms to prevent threats to the state budget system;

- ensuring the state budget efficiency;

- forming budget reserves and structuring budget expenditures;

- improving inter-budget relations and developing budget decentralization; 
- implementing the budget effectiveness and control system;

- unshadowing the economy and funds legalization with their involving into investment within Ukraine;

- minimizing the state deficit, and state debt effective management.

The major target strategic priorities while forming the directions for Ukraine budget security ensuring should be determined the following: ensuring national security interests and implementation of national economic interests; ensuring credit worthiness, financial stability and keeping the balance of Ukraine budget system; decreasing the state debt dependency; effective execution of the revenue and expenditure parts of the consolidated and state budget and public obligations; stimulating the development of budget-forming industries and strategically important enterprises.

The research scientific results were used by the state and local authorities while improving the existing regulatory and methodological provision, and creating policy documents for the safe budget system development and inter-budget relations in Ukraine. In particular, strategic priorities for ensuring budgeta security have been implemented in the work of the Verkhovna Rada of Ukraine Budget Committee when adopting draft bill and preparing appropriate recommendations for legislative documents of the budget process organization.

\section{CONCLUSION}

The study of state policy of budget security of Ukraine ensuring made it possible to define a dominant role and place in the system of financial and economic security of the state and role of state policy. The modern paradigm of security science shows that security is the most important category and a prerequisite for a balanced functioning of the social relations system that provides protection from global challenges and threats.

At the present stage of security science development three basic conceptual approaches to the definition of budget security as an economic category have been formed. System-forming element of budget security in the state is the state budget, which is a multi-dimensional concept. The budget as an instrument of state policy plays a key role in ensuring the socioeconomic development of the state and the realization of its national interests, in particular, the volume and structure of the revenue and expenditure parts of the budget affect the functioning of all economic sectors.

The statement of the theory of economic security as a complex polysystem phenomenon in terms of the essence, structure, characteristics and place of budget security as a dominant component of the financial security of the state, allowed using comparative and correlationregression analysis to establish cause and effect relationships and to identify the main functional dependencies with all the components of the state economic security.

The strategic priorities are proposed, and the criteria of budget policy for strengthening budget security are defined, which envisages formation of favorable macroeconomic environment, development of real sector of economy, stability of state finances and creditworthiness of the state, and financial security of Ukraine.

\section{REFERENCES}

[1] Brook, D. (2012). Budgeting for national security: A whole of government perspective. Journal of Public Budgeting, Accounting \& Financial Management. 24. 32-57. Retrieved from https://doi.org/10.1108/JPBAFM-24-01-2012-B002.

[2] Ringel, I. \& Tishler, Asher. (2011). The government budget allocation process and national security: An application to the Israeli-Syrian arms race. Handbook on the Economics of Conflict. 105-142. 
[3] Baranovskii, O. I. (2014). Філософія безпеки: монографія [Filosofiya bezpeki: monografiya]. Kyiv: UBS NBU, 1, 831.

[4] Bogolib, T. (2016). Бюджетна система України: нова реальність і глобальні виклики [Byudzhetna sistema Ukraini: nova realnist i globalni vikliki]. Economic Annals-XXI, 156(12), 41-43. http://dx.doi.org/ 10.21003/ea.V156-0009

[5] Cramer, J. K. (2007). National security panics : overestimating threats to national security. Retrieved from

https://www.researchgate.net/publication/279839445_National_security_panics_overestimatin g_threats_to_national_security

[6] European Commission (2019). Europe 2020: European Union's ten-year growth strategy. Retrieved from http://ec.europa.eu/europe2020/index_en.htm

[7] Babets, I.G. (2013). Методичні підходи до оцінювання бюджетної безпеки України [Metodichni pidkhodi do otsinyuvannya byudzhetnoi bezpeki ukraini]. Scientific Journal NLTU Ukraine, 23, 87-93.

[8] Martinyuk, V. (2013). Оцінка стану національної економіки на основі інтегрального показника економічної безпеки держави [Otsinka stanu natsionalnoi ekonomiky na osnovi intehralnoho pokaznyka ekonomichnoi bezpeky derzhavy]. Economics, management, entrepreneurship, 25 (I), 179-188. Retrieved from http://nbuv.gov.ua/UJRN/ecmepi_2013_25\%281\%29_22

[9] Onishchenko, S., Matkovskyi, A. \& Puhach, A. (2014). Аналіз загроз економічній безпеці України в умовах інноваційного розвитку економіки [Analiz zagroz ekonomichnii bezpetsi Ukraini v umovakh innovatsiinogo rozvitku ekonomiki]. Economic Annals-XXI. 12(2), 8-11. Retrieved from http://soskin.info/userfiles/file/2014/12_2014/2/Onishchenko_Matkovskyi_Puhach.pdf

[10] Ministry of Economic Development and Trade of Ukraine (2019). Economic situation and forecasts [online]. Retrieved from http://www.me.gov.ua.

[11] On the internal and external situation of Ukraine in the national security (2017). Analytical report to an extraordinary President of Ukraine to the Verkhovna Rada of Ukraine. Kyiv: National Institute for Strategic Studies.

[12] Weisstanner, D. (2017). The fiscal benefits of repeated cooperation: Coalitions and debt dynamics in 36 democracies. Journal of Public Policy, 37 (2), 143-172. doi:10.1017/S0143814X16000040.

[13] Pirozhkov, S. L. (2000). Економічна безпека України у контексті економічних реформ [Ekonomichna bezpeka Ukraïni u konteksti ekonomichnikh reform]. Economic Development Strategy of Ukraine, 2-3, 9-21.

[14] State Statistics Service of Ukraine (2019). Statistic information [online]. Retrieved from http://www.ukrstat.gov.ua.

[15] The World Bank (2019). Indicators [online]. Retrieved from http://www.worldbank.org

[16] The World Economic Forum (2019). Global Competitiveness Report 2019: How to end a lost decade of productivity growth. Retrieved from

http://www3.weforum.org/docs/WEF_TheGlobalCompetitivenessReport2019.pdf.

[17] Onyshchenko S. V. \& Maslii O. A. (2017). Orhanizatsiino-ekonomichnyi mekhanizm uperedzhennia zahroz biudzhetnii bezpetsi ekonomiky Ukrainy. Naukovyi visnyk «Polissia». Chernihiv : Chernihiv. nats. tekhnol. un-t, 1 (9), ч.1., 176-184.

[18] Sukhorukov, A. \& Ostapchuk, D. (2014). Синергетичний механізм формування системи економічної безпеки держави [Sinergetichnii mekhanizm formuvannya sistemi ekonomichnoi bezpeki derzhavi]. Economic Annals-XXI, 1-2(1), 19-22. Retrieved from http://soskin.info/userfiles/file/2014/12_2014/1/Sukhorukov_Ostapchuk.pdf 
State Policy for Ensuring Budgetary Security of Ukraine in Terms of Financial Globalization

[19] Johnson, A. \& Rauhaus, B. \& Webb-Farley, K. (2020). The COVID-19 pandemic: a challenge for US nonprofits' financial stability. Journal of Public Budgeting, Accounting \& Financial Management. Retrieved from https://doi.org/10.1108/JPBAFM-06-2020-0076.

[20] Kolisnik, O.J. (2009). Бюджетна безпека у забезпеченні стратегії сочіальноекономічного розвитку держави [Byudzhetna bezpeka u zabezpechenni strategï sotsial'noekonomichnogo rozvitku derzhavi]. Ternopil: TNEU, 20.

[21] Varnaliy, Z., Onishchenko, S. \& Masliy, A. (2016). Threat prevention mechanisms of Ukraine's economic security. Economic Annals-XXI. 159(5-6), 20-24. http://dx.doi.org/10.21003/ea.V159-04.

[22] Vlasyuk, O.S. (2016). Національна безпека України: еволючія проблем внутрішньої політики [Natsionalna bezpeka Ukraini: evolyutsiya problem vnutrishnoi politiki]. Kyiv: NISS, 528. Retrieved from http://kh.niss.gov.ua/content/articles/files/Vlasuk-fin-99d56.pdf

[23] Tănase, G. L. (2014). Difficulties of the Budgeting Process and Factors Leading to the Decision to Implement this Management Tool. Procedia Economics and Finance, Volume 15, 466-473. Retrieved from https://doi.org/10.1016/S2212-5671(14)00484-5

[24] Dets, V.F. (2008). Міжбюджетне регулювання в системі забезпечення економічної безпеки держсави [Mizhbyudzhetne regulyuvannya v sistemi zabezpechennya ekonomichnoi bezpeki derzhavi]. Kyiv: NIPMS, 21.

[25] Sarvananthan, M. (2007). The Government Budget: A Critical Appraisal with Reference to Transparency and Accountability. PPID Working Paper Series. Retrieved from https://doi.org/10.2139/ssrn.2820917. 